\title{
MRI が有用であったピーナッツ気管支異物
}

\author{
与座 朝 義*, 中村 匡*, 我 那覇 仁**
}

\section{Usefullness of MRI in the Diagnosis of the Bronchial Peanuts Foreign Body}

\author{
Tomoyoshi Yoza, M.D., ${ }^{*}$ Tadasu Nakamura, M.D., ${ }^{*}$ and \\ Hitoshi Ganaha, M.D.** \\ *Division of Otolaryngology and **Division of Pediatrics, \\ Okinawa Prefectural Chubu Hospital, Okinawa
}

\begin{abstract}
We used MRI (T1 weighted image) for the diagnosis of the case of the bronchial peanuts foreign body in which usual endoscopic procedure was very difficult because of reactive bronchial stenosis. The patient was a 1-year 2-month old boy and his body weight was $8.0 \mathrm{~kg}$. MRI could visualize the figure of peanut which was not visible in the plain X-ray film because of radiopacity. At the time of removal of foreign body, we intubated unilaterally to the affected bronchus using the endotracheal tube ( $3.5 \mathrm{~mm}$ ID.) in which two additional pores was made, under the guidance of a fiberscope (diameter $1.8 \mathrm{~mm}$ )

This procedure was very effective to the observation of the stenotic bronchial mucosa and to the approach to the foreign body through the bronchial stenosis.
\end{abstract}

Key words : MRI, peanuts, bronchus, foreign body

\section{I 、はじめに}

ピーナッツの気管支異物はX 線透過性であ るため, 従来の X 線を用いた画像診断では異物 影を直接描写することが困難で, その診断は気 管支狭窄から生じる二次的変化から疑診し, 内 視鏡検査で確定診断するのが通常の診断手順で あった。したがって，通常の内視鏡検査が困難 な症例に抽いては診断が困難となる。近年, MRI が各領域に導入され, その有用性が報告さ れているが，ピーナッツ気管支異物における報 告は, 北中ら ${ }^{21}$, 山岨ら ${ }^{31}$ の学会報告がみられる のみで，著者らが検索したかぎりでは文献とし てはまだ報告例がない。最近, MRI が有用で あったピーナッツ気管支異物を経験したので報

*沖縄県立中部病院耳舆科, $* *$ 同・小览科

別刷請求： $7904-22$ 沖縄県具志川市字宮里208-3 沖縄県立中部病院耳鼻科与座朝義

投稿受付：1992年2月 7 日
告する。

$$
\begin{aligned}
& \text { II. 症 例 } \\
& \text { 症 例：1歳 } 2 \text { 力月の男子 } \\
& \text { 初 診: 1991年 } 4 \text { 月 } 9 \text { 日 } \\
& \text { 主 訴: 咳嗽 }
\end{aligned}
$$

既往歴：特記すべきことなし 家族歷：特記すべきことなし

現病歴：1991年 3 月25日頃, ピーナッツ入り のクッキーを食べているときにむせて激しく泣 いたがまもなく軽快した。その後咳嗽と微熱が 続き，両親は風邪と思い10日間様子を見ていた が軽快せず，4月 5 日に近医を受診した。聴診 と胸部 X 線写真より気管支異物を疑われ, 某病 院に紹介された。紹介先の病院で気管支ファイ バースコープの検査を受けたが異物は確認でき ず，4月 9 日当院に紹介となった。

入院時の現症と検查結果：体重 $8.0 \mathrm{~kg}$ 。聴診 上, 左肺の呼吸音低下。胸部 X 線写真で左肺気 


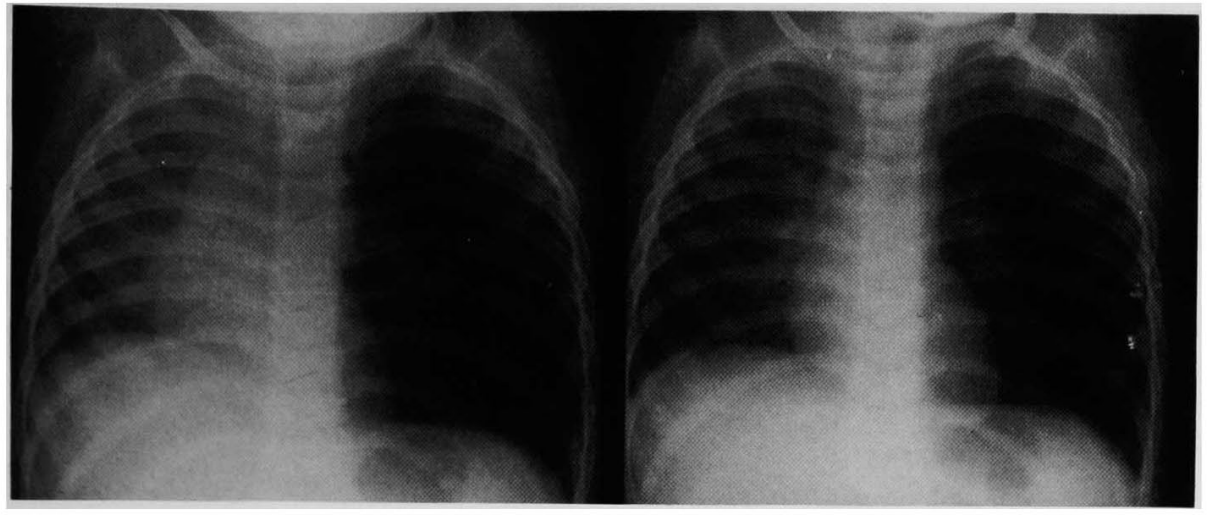

図 1 入院時の胸部 X 線像 (左：呼気, 右 : 吸気)

左肺気腫像と吸気時に縦隔心陰影の患側への移動（ホルックネヒトサイン）を認める。

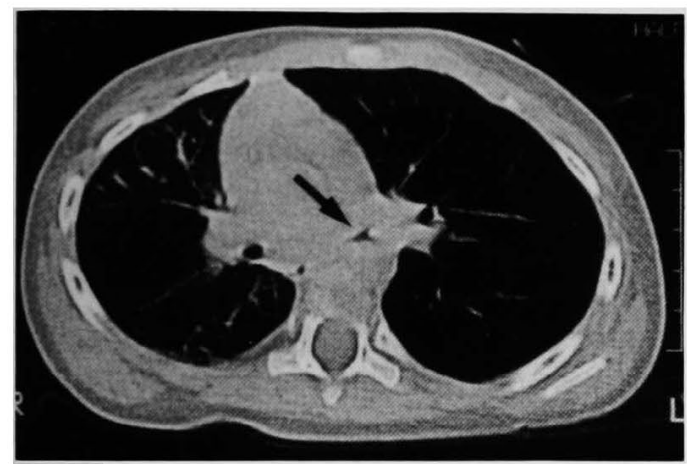

図 2 CT 像

左主気管支の狭窄を認める (矢印)が, 異物は確認で きない。

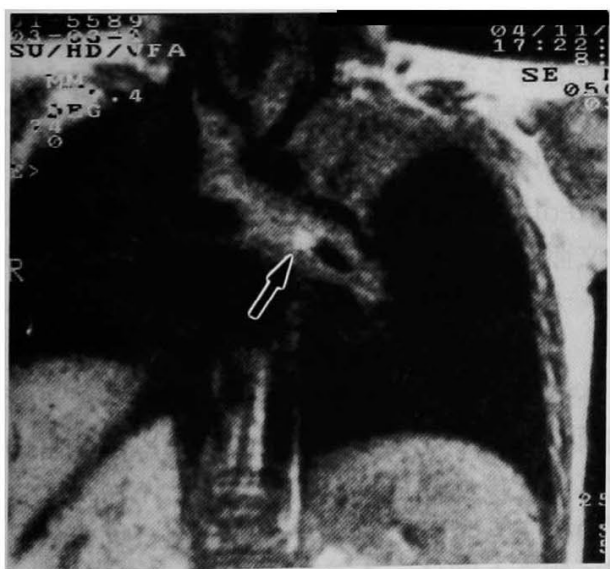

図 3 T1 強調 MRI 像（SE 法：TR500 ms, TE30 $\mathrm{ms})$

左主気管支の狭窄像と, その末梢部の気管支内に高 信号域 (矢印)を認める。

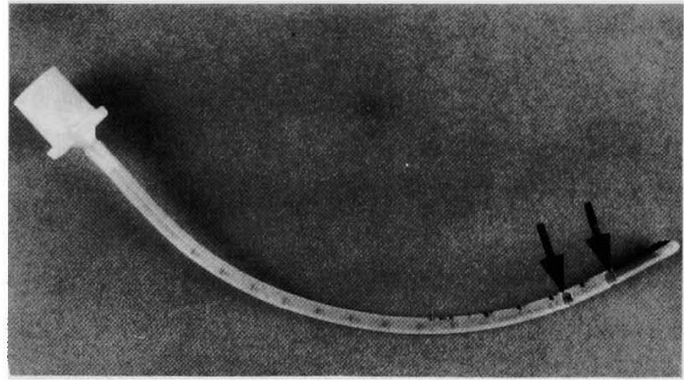

図 4 異物摘出時に使用した挿管チューブ 尖端から約 $2 \mathrm{~cm}$ と $3.5 \mathrm{~cm}$ の部位に径約 $3 \mathrm{~mm}$ の側 孔を開けてある。

腫，ホルックネヒトサイン陽性を示し（図 1), CT 像では左主気管支の狭窄は認めたが異物は 確認できなかった（図 2)。

経 過：肉芽または気管支粘膜の腫脹のみに よる気管支狭窄とも考えられたが, 異物の存在 も否定できず，4 月10日, 内径 $4 \mathrm{~mm}$ のベンチ レーション・ブロンコスコープによる硬性気管 支鏡検査を施行した。所見は左主気管支の腫脹, 発赤を認め, 狭窄部はチェックバルブ様の動き を示した。狭窄部より末梢への硬性鏡の挿入を 試みたが，狭窄のため硬性鏡の通過は困難であ り, 出血をきたしたため, それ以上の操作を断 念した。

4 月11日, T 1 強調の MRI 検査（SE 法： TR500 ms，TE30 ms）で，左主気管支狭窄部の 末梢にピーナッツと思われる高信号域を認めた (図 3 )。異物除去のための内視鏡検査を再度行 


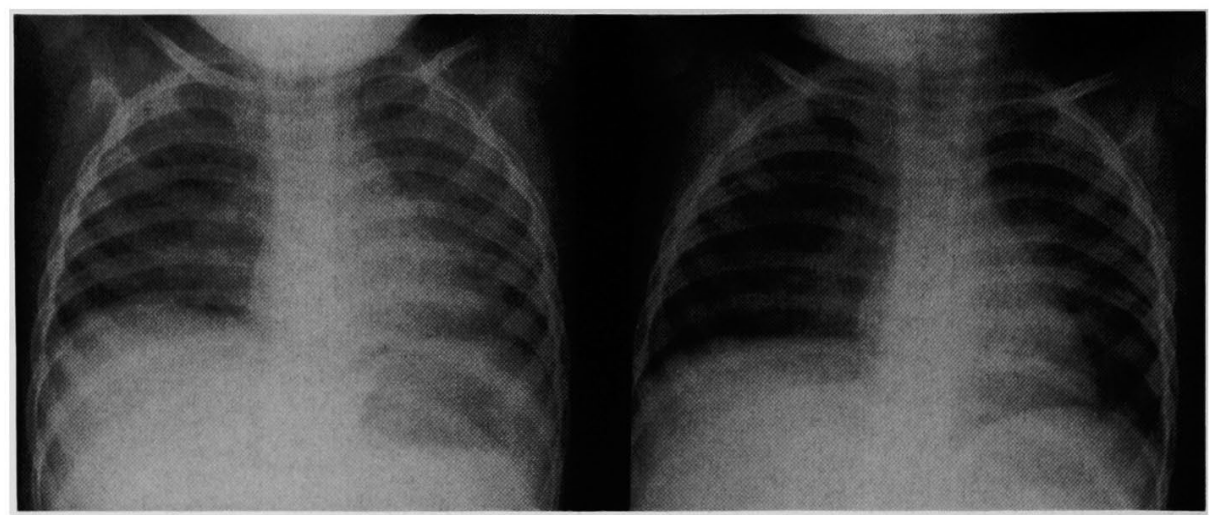

図 5 異物除去 2 週間後の胸部 X 線像（左：呼気, 右：吸気）

左肺気腫像, ホルックネヒトサインともに改善している。

うにあたり，著者らは以下のような工夫を行っ た。すなわち $3.5 \mathrm{~mm}$ の挿管チューブの尖端か ら約 $2 \mathrm{~cm}$ と $3.5 \mathrm{~cm}$ の 2 力所に $3 \mathrm{~mm}$ の側孔 を作製し(図 4 ), 挿管チューブの内腔から直径 $1.8 \mathrm{~mm}$ (マチダ PF18S)のファイバースコープ で観察しながら片肺抻管の要領で, 左主気管支 に挿入していく方法をとった。右肺の換気は側 孔経由で問題なく可能であった。この方法によ り狭窄部を徐々に広げ，気管支粘膜を観察しな がら，狭窄部を越えて末梢部まで観察すること ができた。狭窄部を越えた直下にピーナッッの 溶けたような泥状物を認めた。泥状物を吸引除 去後, 狭窄部にボスミンおよびデカドロン液を 注入し,さらに生食水で洗浄し処置を終了した。 術後は微熱が認められたが, 経過は順調で 4 月18日に軽快退院した（図 5 )。

\section{III. 考 案}

ピーナッツは小児の下気道異物で最も多いも のであるが, X 線透過性のため時に診断が困難 な症例に遭遇する。ピーナッツが気管内に存在 する場合には, 頸部の単純 X 線写真で異物影を とらえた症例をわれわれも経験しており,また， CT スキャンにより診断し得た症例の報告もみ られる”。しかし，気管支内に存在する場合は， これまでのX線による画像診断では異物の映 像を直接写すことができず，気管支狭窄から生 じる二次的変化から推測する以外に方法がな かった。したがって内視鏡検査で確定診断する
ことになるが，本症例のように内視鏡検査が困 難な症例または困難な部位では診断が極めて困 難となる。MRI はピーナッツのように脂肪を多 く含む領域を高信号域として描出するため, 気 管, 気管支内のピーナッツ異物の診断は飛躍的 に容易になるものと期待できる。

また, CT スキャンに比較して MRI が有利な 点は断層面が自由に選択できるため気管支の長 軸方向の断層像を得ることが可能で, 異物の部 位診断も容易かつ正確にできる点である。ピー ナッツ気管支異物の MRI 診断に関しては北中 ら2), 山岨ら ${ }^{3)}$ 学会報告があるのみである。T1 強調と $\mathrm{T} 2$ 強調のどちらが良いかについては基 礎的には脂肪は $\mathrm{T} 1$ 強調, T2 強調 ( SE 法) とも に高信号とされている4)が, 北中ら, 山岨らは特 に T1 強調が有用と述べている。著者らも $\mathrm{T} 1$ 強調を用いた。

Medline で過去20年間, Joice で過去 5 年間 を文献検索したかぎりでは国内外には気管支 ピーナッツ異物と MRI に関する文献はなかっ た。

本症例では体重 $8 \mathrm{~kg}$ の小児で,さらに気管支 粘膜の腫脹による気管支狭窄のため, 通常の硬 性気管支鏡はもちろん気管支ファイバースコー プの検査も困難であった。著者らは捰管チュー ブに側孔を開け，そこから健側肺の換気を行い つつ, 挿管チューブの尖端を患側の気管支に挿 入し, 気管支狭窄部を押し広げながら通過する 方法を考案した。内径 $3.5 \mathrm{~mm}$ の插管チューブ 
内で使用できるファイバーは，尖端部が非可動 性の直径1.8 mm のマチダ PF18S しかなかっ たため，捜管チューブの誘導は患者の体位を変 えながら片肺挿管の要領で行った。気管支狭窄 部の観察は, ファイバースコープの尖端が粘膜 に接触することがないため容易であった。

本症例のように小児で気管支が小さく，しか も気管支粘膜の腫脹による気管支狭窄のため通 常の内視鏡が困難な症例には有用な方法と思わ れる。このような方法は, 著者が猟集し得た文 献の範囲では報告がなかった。

\section{IV. まと め}

小児の気管支異物で気管支狭窄があり, 通常 の内視鏡検査が困難な症例で, MRIによりピー ナッツを描写でき極めて有用であった。また,
挿管チューブと極細ファイバースコープを用い た内視鏡の方法を紹介した。

本論文の要旨は, 第43回日本気管食道科学会 (1991 年, 京都) においてロ演した。

\section{文献}

1 ）田中 治, 兵 行和, 松永 喬 - 他: X 線透過 性下気道異物 25 症例の診断について。 日気食会 報, 36：309-316, 1985 .

2 ）北中幸子, 横小路雅文, 水野正浩·他：ピーナッ ツ気管内異物における MRI の有用性につい て。 日児誌, $2: 394,1991$.

3 ) 山岨達也, 水野正浩, 小林武夫・他：ピーナッ ツ気道異物に対するMRI の応用. 第43回日本 気管食道科学会プログラム・予稿集, p.118, 1991.

4 ）三浦寿美子, 多田信平: MRI の基礎知識. JOHNS, $5: 1311-1327,1989$. 